\title{
UTICAJ EGFR MUTACIJSKOG STATUSA NA KLINIČKI TOK BOLESTI U PACIJENATA SA ADENOKARCINOMOM PLUĆA
}

\author{
Lora Novaković Lacković, Ljilja Tadić Latinović, Mirko Stanetić, Marinko Vučić, Dušan \\ Janičić
}

SAŽETAK: Molekularna patologija adenokarcinoma pluća, vjerovatno je bolje definisana u odnosu na druge vrste tumora, zbog njegove učestalosti, hirurške pristupačnosti ali $i$ zbog uspjeha u identifikovanju klinički važnih mutacija u ovoj vrsti karcinoma. EGFR (engl. Epidermal Growth Factor Receptor) mutacije su do sada klinički najrelevantnije mutacije u plućnom karcinomu, te bitan prediktivni marker za terapiju ciljnim hemoterapeuticima. Transmembranski glikoprotein iz grupe receptora epidermalnog faktora rasta je prisutan u $10 \%$ do $15 \%$ slučajeva uznapredovalog nemikrocelularnog karcinoma pluća.

Ispitivanjem je obuhvaćeno 29. pacijenata kojima je u periodu od maja 2012. godine do decembra 2016. godine u Klinici za plućne bolesti UKC RS proveden dijagnostički $i$ terapijski tretman adenokarcinoma pluća. Kod svih pacijenata je citološki i/ili histološki potvrđen adenokarcinom pluća, a u Zavodu za patologiju UKC RS je provedeno dodatno molekularno testiranje postojećeg materijala. Studija potvrđuje navode literature o dominatnosti histološkog tipa adenokarcinoma te čě́ćoj pojavnosti u ženskoj populaciji $i$ u kategoriji nepušača. Studija pokazuje da su srednje vrijeme trajanja tretmana inhibitorima tirozin kinaze kao i srednje vrijeme preživljavanja duži od godinu dana.

\section{UVOD:}

Novina u shvatanju liječenja svih malignih tumora je detekcija biohemijskih i molekularnih mutacija, koje predstavljaju potencijalne prognostičke parametre i mjesta djelovanja novih terapeutika u liječenju malignih tumora ${ }^{[1]}$. Genotipizacija nemikrocelularnog karcinoma pluća sa identifikacijom prisustva specifičnih tumorskih gena, omogućava ljekarima da u kliničkom radu prepoznaju pacijente koji će (i jednako važno, pacijente koji neće) reagovati na pojedine ciljne ljekove ${ }^{[2]}$. Personalizovani tretmani postaju standard njege u pacijenata sa nemikrocelularnim karcinomom pluća ${ }^{[3]}$. Ovakav vid tretmana ima za cilj poboljšanje preživljavanja, produženje vremena do progresije bolesti i obezbjeđenje boljeg kvaliteta života pacijenata ${ }^{[4]}$.

Adenokarcinom je predominatna histološka podgrupa nemikrocelularnog karcinoma pluća. Ovaj podtip nemikrocelularnog karcinoma pluća se, kao i skvamozni karcinom, povezuje sa navikom pušenja duvana, mada je u oboljeloj populaciji češći kod nepušača i žena $[5,6]$. Postojanje udaljenih metastaza vrlo je često i karakteristično za adenokarcinom ${ }^{[7]}$.
Molekularna patologiji adekarcinoma, vjerovatno je bolje definisana u odnosu na druge vrste tumora, zbog njegove učestalosti, hirurške pristupačnosti ali i zbog uspjeha u identifikovanju klinički važnih mutacija u ovoj vrsti karcinoma ${ }^{[8]}$. EGFR mutacije su do sada klinički najrelevantnije mutacije u plućnom karcinomu, te bitan prediktivni marker za terapiju ciljnim hemoterapeuticima ${ }^{[9]}$. Transmembranski glikoprotein iz grupe receptora epidermalnog faktora rasta je prisutan u $10 \%$ do $15 \%$ slučajeva uznapredovalog nemikrocelularnog karcinoma pluća. Oko 90\% svih nemikrocelularnih karcinoma pluća sadrži tzv. Divlji tip EGFR (wt, eng. wild type), što znači da u EGFR genu nema mutacija ${ }^{[10]}$. Ovi pacijenti, sa EGFR negativnim tumorima su manje osjetljivi na terapiju inhibitorima tirozin kinaze. Bez obzira na etičku pripadnost, EGFR miutacije su češće u tumorima osoba ženskog pola, nepušača (definisano kao manje od 100 cigareta u životi svakog pacijenta) sa histologijom adenokarcinoma. Međutim, EGFR mutacije se mogu naći i u drugim podgrupama nemikrocelularnog karcinoma pluća, te kod nemikrocelularnog karcinoma u bivših i sadašnjih pušača. 
Mala podgrupa pušača, njih $5-10 \%$ su test pozitivni, što znači da će imati korist od terapije inhibitorima tirozin kinaze.

U ogromnoj većini slučajeva, EGFR mutacije se ne poklapaju sa drugim mutacijama koje se nalaze $\mathrm{u}$ nemikrocelularnom karcinomu pluća ${ }^{[11]}$. Oko 90\% EGFR mutacija su na egzonu 19 ili na egzonu 21. Mutacije u okviru EGFR egzona 20, povezane su sa rezistencijom na inhibitore tirozin kinaze.

Tabela 1. - Prognostički i prediktivni značaj mutacija

\begin{tabular}{|c|c|c|}
\hline & PROGNOSTIČKI & PREDIKTIVNI \\
\hline EGFR & $\begin{array}{c}\text { Bolja prognoza } u \\
\text { bolesnika sa EGFR } \\
\text { mutacijama }\end{array}$ & $\begin{array}{c}\text { EGFR mutacija je } \\
\text { prediktivna za odgovor na } \\
\text { inhibitore tirozin kinaze }\end{array}$ \\
\hline
\end{tabular}

Tradicionalnim načinom liječenja, primjenjivanim 40 godina, ukupno preživljavanje (OS, engl. - overall survival) bolesnika sa metastatskim karcinomom pluća nije bilo duže od 1 godine. Najnoviji podaci pokazuju da je medijana preživljavanja kod pacijenata sa uznapredovalim nemikrocelularnim karcinomom pluća i prisutnim EGFR mutacijama, koji su tretirani inhibitorima tirozin kinaze prve generacije produženo na 2 godine što je dvostruko duže u odnosu na ukupno preživljavanje kod pacijenata tretiranih samo tradicionalnim načinom liječenja $[12,13]$.

\section{CILJ:}

Cilj rada je retrospektivna analiza uticaja mutacijskog statusa u pacijenata sa adenokarcinomom pluća na klinički tok bolesti, odnosno procjena efikasnosti primjene inhibitora tirozin kinaze u prvoj liniji terapije, te određivanje korelacije demografskih, histoloških i molekularnih karekteristika.

\section{MATERIJAL I METODE:}

Ispitivanjem je obuhvaćeno 29. pacijenata kojima je u periodu od maja 2012. godine do decembra 2016. godine u Klinici za plućne bolesti UKC RS proveden dijagnostički i terapijski tretman adenokarcinoma pluća. Kod svih pacijenata je citološki i/ili histološki potvrđen adenokarcinom pluća. U Zavodu za patologiju UKC RS od maja 2012. godine se radi molekularno testiranje (eng. Polymerase chain reaction) metodom u realnom vremenu (eng. real time PCR).

Dakle, na ispitivanom uzorku provedeno je dodatno molekularno testiranje postojećeg materijala. U obrađenom vremenskom intervalu, na osnovu odluke pulmološko - onkološkog konzilijuma provedeno je liječenje inhibitorima tirozin kinaze kao prva linija liječenja, adjuvantni tretman ili terapija održavanja. Kriterijumi za ordiniranje inhibitora tirozin kinaze jeste pozitivan EGFR mutacijski status, te dobro opšte stanje pacijenta. Traženi parametri su uzeti iz istorija bolesti svakog pojedinačnog pacijenta te evidencije Zavoda za patologiju UKC RS. Podaci su standardno uneseni u bazu podataka, te obrađeni deskriptivnim statističkim metodama i prikazani grafikonima $\mathrm{i}$ tabelarno.

\section{REZULTATI:}

Prosječna starosna dob ispitanika je 61 godina. $\mathrm{U}$ ispitivanom uzorku, prema polu dominiraju žene sa $72,5 \%$ te $27,5 \%$ ispitanika muškog pola.

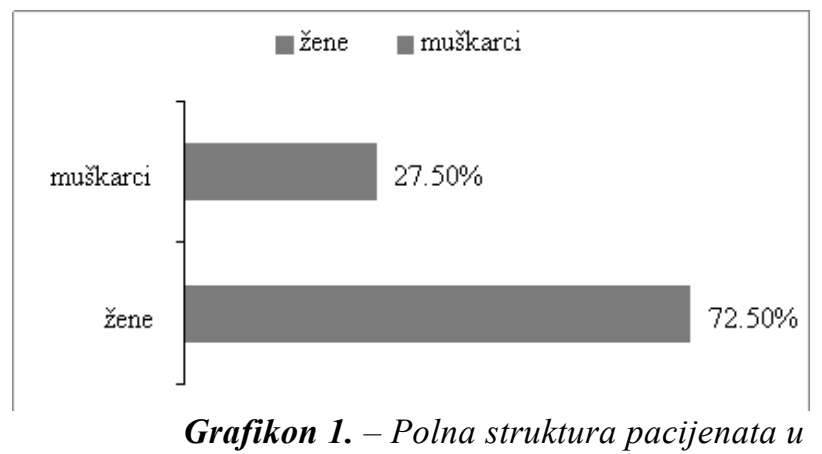
uzorku

$\mathrm{U}$ ispitivanom uzorku dominantni su nepušači sa $72,5 \%$ zastupljenošću te pušači sa $27,5 \%$.

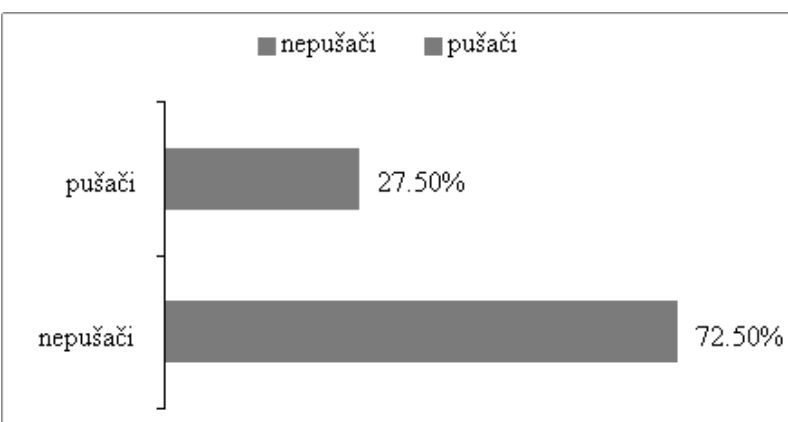

Grafikon 2. - Odnos ispitanika prema pušačkom statusu 
Prema stadijumu bolesti najveći broj ispitanika je bio u IV stadijumu bolesti - 58,6\%; zatim u IIIA $13,8 \%$ i IB - 13,8\% stadijumu bolesti; te po $3,45 \%$ ispitanika u IA, IIA, IIB i nepoznatom stadijumu bolesti.

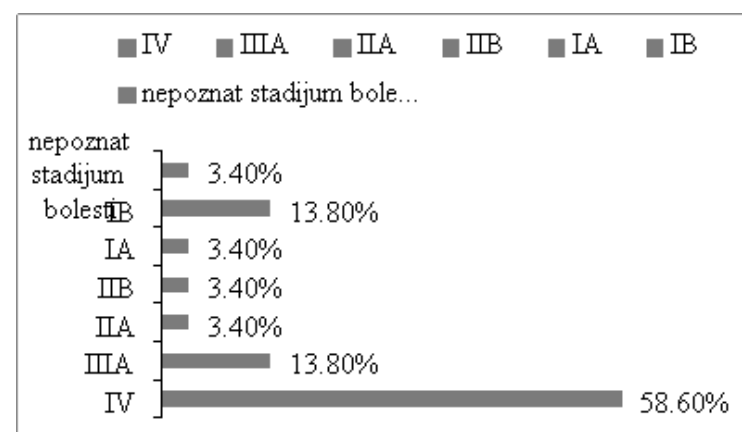

Grafikon 3. - Podjela prema stadijumu bolesti

Prema učestalosti mutacija $\mathrm{u}$ analiziranom uzorku, najčešće detektovane mutacije su na egzonu 19 (48,3\%), zatim mutacije na egzonu 21 (38\%). Slijede mutacije na egzonu $20(10,3 \%)$ i mutacije na egzonu 18 (3,4\%).

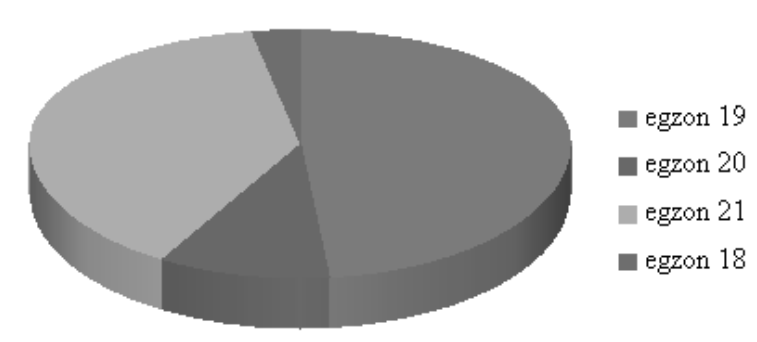

Grafikon 4. - Učestalost EGFR mutacija

Mutacije su detektovane u $72,4 \%$ ispitanika ženskog pola, te $27,6 \%$ ispitanika muškog pola.

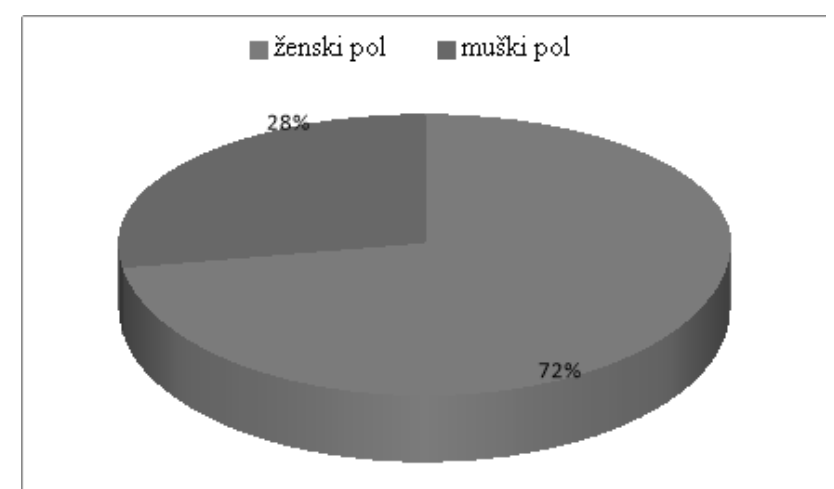

Grafikon 5. - Učestalost EGFR mutacija prema polu
Od ukupnog uzorka ispitanika, primjena inhibitora tirozin kinaze je indikovana u 89,7\% ispitanika u odnosu na detektovane mutacije.

Prva linija terapije inhibitorima tirozin kinaze je provedena u $15,4 \%$ pacijenata. Terapija održavanja inhibitorima tirozin kinaze provedena je u $57,7 \%$ pacijenata, a kod 3,8\% pacijenata inhibitori tirozin kinaze su primjenjeni adjuvantno. Kod 19,2\% pacijenata terapija nije započeta zbog lošeg opšteg stanja (ECOG 3/4). U momentu zaključivanja podataka (XII/2016.) 3,8\% pacijenata (1 pacijent) je čekalo uključenje u monoterapijski tretman.

Srednje vrijeme dužine trajanja tretmana inhibitorima tirozin kinaze je 13,5 mjeseci sa rasponom od 2-42 mjeseca.

Srednje vrijeme dužine trajanja tretmana inhibitorima tirozin kinaze primjenjenim u prvoj liniji je 8 mjeseci. Srednje vrijeme trajanja tretmana inhibitorima tirozin kinaze primjenjenim $\mathrm{u}$ prvoj liniji $\mathrm{u}$ ispitanika ženskog pola je 4 mjeseca (uz napomenu da su u vrijeme zaključenja podataka obje žive i u tretmanu). Ispitanici muškog pola imaju srednje vrijeme trajanja tretmana inhibitorima tirozin kinaze primjenjenim $u$ prvoj liniji od 12 mjeseci (u vrijeme zaključenja podataka oba su isključena iz tretmana). Poredeći srednje vrijeme trajanja tretmana inhibitorima tirozin kinaze u odnosu na pol ispitanika, nije uočena statistička značajnost $\mathrm{p}>0,05$.

Ispitanici u kategoriji nepušača imaju srednje vrijeme trajanja tretmana inhibitorima tirozin kinaze primjenjenim u prvoj liniji od 6,3 mjeseca. U kategoriji pušača sa inhibitorima tirozin kinaze primjenjenim u prvoj liniji je samo jedan pacijent.

Tabela 2. - Dužina tretmana inhibitorima tirozin kinaze u prvoj liniji Ženski pol Muški pol Nepušači

\begin{tabular}{l|lll}
$\begin{array}{l}\text { Srednje vrijeme } \\
\text { trajanja tretmana }\end{array}$ & 4 mjeseca & 12 mjeseci & 6,3 \\
inhibitorima & & mjeseca \\
tirozin kinaze & & \\
u prvoj liniji & & \\
& &
\end{tabular}

Srednje vrijeme trajanja tretmana inhibitorima tirozin kinaze primjenjenim u terapiji održavanja je 15,7 mjeseci. Ispitanici ženskog pola imaju srednje vrijeme trajanja tretmana inhibitorima tirozin kinaze primjenjenim u terapiji održavanja od 15,5 mjeseci. Ispitanici muškog pola imaju srednje vrijeme trajanja tretmana inhibitorima tirozin 
kinaze primjenjenim u terapiji održavanja od 15,8 mjeseci. Razlika između ove dvije grupe (muški/ženski pol) nije statistički značajna $p>0,05$.

Ispitanici u kategoriji nepušača imaju srednje vrijeme trajanja tretmana inhibitorima tirozin kinaze primjenjenim u terapiji održavanja od 20 mjeseci. Ispitanici $u$ kategoriji pušača imaju srednje vrijeme trajanja tretmana inhibitorima tirozin kinaze primjenjenim $u$ terapiji održavanja od 3,75 mjeseci. Razlika između ove dvije grupe nije statistički značajna $\mathrm{p}>0,05$ (grupe nesrazmjerne u veličini).

Tabela 3. - Dužina tretmana inhibitorima tirozin kinaze u terapiji održavanja

Žanski Muški Nepuša Pušači pol pol či

\begin{tabular}{|c|c|c|c|}
\hline $\begin{array}{l}\text { Srednje vrijeme trajanja } \\
\text { tretmana inhibitorima } \\
\text { tirozin kinaze u terapiji } \\
\text { održavanja }\end{array}$ & $\begin{array}{cc}15,5 & 15,8 \\
\text { mjeseci } & \text { mjeseci }\end{array}$ & $\begin{array}{c}20 \\
\text { mjeseci }\end{array}$ & $\begin{array}{l}3,75 \\
\text { mjese } \\
\text { ci }\end{array}$ \\
\hline
\end{tabular}

Srednje vrijeme dužine trajanja tretmana inhibitorima tirozin kinaze primjenjenim u prvoj liniji je 8 mjeseci. Srednje vrijeme dužine trajanja tretmana inhibitorima tirozin kinaze primjenjenim u terapiji održavanja je 15,7 mjeseci. Dužina trajanja tretmana inhibitorima tirozin kinaze $\mathrm{u}$ terapiji održavanja je veća ali bez statističke značajnosti $\mathrm{p}>0,05$.

Tabela 4. - Dužina tretmana inhibitorima tirozin kinaze u prvoj liniji i terapiji održavanja Prva linija Terapija održavanja

$\begin{aligned} & \text { Srednje vrijeme trajanja } \\ & \text { tretmana inhibitorima tirozin }\end{aligned}$
kinaze

Vrijeme preživljavanja definišemo kao period od datuma dijagnoze do datuma smrti ili zadnje kontrole. Srednje vrijeme preživljavanja pacijenata $\mathrm{u}$ ispitivanom uzorku je 14,5 мјесеци. 48\% ispitanika ima preživljavanje $>1$ godine, a $26 \%$ ispitanika ima preživljavanje $>2$ godine. Kod 7\% ispitanika je dužina vremena preživljavanja nepoznata (pacijent je liječenje nastavio u drugoj državi).

Srednje vrijeme preživljavanja $\mathrm{u}$ ispitanika ženskog pola je 12,6 mjeseci. Kod ispitanika muškog pola je srednje vrijeme preživljavanja 21 mjesec. Srednje vrijeme preživljavanja u odnosu na pol ne pokazuje statističku značajnost $\mathrm{p}>0,05$.

Srednje vrijeme preživljavanja u kategoriji nepušača iznosi 16,2 mjeseci, a u kategoriji pušača 10,4 mjeseci. Srednje vrijeme preživljavanja u odnosu na pušački status ne pokazuje statističku značajnost $\mathrm{p}>0,05$.

Tabela 5. - Vrijeme preživljavanja u odnosu na pol $i$ pušački status Ženski pol Muški pol Nepušači Pušači

\begin{tabular}{l|cccc}
$\begin{array}{l}\text { Srednje } \\
\text { vrijeme } \\
\text { preživljavanj }\end{array}$ & $\begin{array}{c}12,6 \\
\text { mjeseci }\end{array}$ & 21 mjesec & $\begin{array}{c}16,2 \\
\text { mjeseci }\end{array}$ & $\begin{array}{c}10,4 \\
\text { mjeseci }\end{array}$ \\
& & & & \\
& & & &
\end{tabular}

Srednje vrijeme preživljavanja pacijenata kod kojih su inhibitori tirozin kinaze primjenjeni $\mathrm{u}$ prvoj liniji terapije iznosi 13 mjeseci. U odnosu na pol, srednje vrijeme preživljavanja u ispitivanih žena sa inhibitorima tirozin kinaze u prvoj liniji je 5 mjeseci, a u ispitivanih muškaraca je 21 mjesec. $\mathrm{U}$ analiziranom uzorku srednje vrijeme preživljavanja je četverostruko veće u ispitanika muškog pola. Pomenuta razlika nije statistički značajna i ne može se govoriti o zakonitosti $(\mathrm{p}>0,05)$.

Ispitanici svrstani u kategoriju nepušača a kod kojih je terapija inhibitorima tirozin kinaze sprovedena u prvoj liniji imali su srednje vrijeme preživljavanja 11,3 мјесеци.

Tabela 6. - Vrijeme preživljavanja sa inhibitorima tirozin kinaze u prvoj liniji

\begin{tabular}{|c|c|c|c|}
\hline & $\begin{array}{c}\text { Ženski } \\
\text { pol }\end{array}$ & $\begin{array}{c}\text { Muški } \\
\text { pol }\end{array}$ & $\begin{array}{c}\text { Nepuš } \\
\text { ači }\end{array}$ \\
\hline $\begin{array}{l}\text { Srednje vrijeme preživljavanja sa } \\
\text { inhibitorima tirozin kinaze u prvoj } \\
\text { liniji }\end{array}$ & $\begin{array}{c}5 \\
\text { mjeseci }\end{array}$ & $\begin{array}{c}21 \\
\text { mjesec }\end{array}$ & $\begin{array}{c}11,3 \mathrm{mj} \\
\text { eseci }\end{array}$ \\
\hline
\end{tabular}

Srednje vrijeme preživljavanja pacijenata kod kojih su inhibitori tirozin kinaze primjenjeni $\mathrm{u}$ terapiji održavanja iznosi 19,2 mjeseca. U odnosu na pol, srednje vrijeme preživljavanja $u$ ispitivanih žena sa inhibitorima tirozin kinaze $u$ terapiji održavanja je 20,6 mjeseci, a u ispitivanih muškaraca je 20,6 mjeseci. Poredeći srednje vrijeme preživljavanja u odnosu na pol ispitanika, nije uočena statistička značajnost $p>0,05$. 
Ispitanici svrstani u kategoriju nepušača imali su srednje vrijeme preživljavanja sa inhibitorima tirozin kinaze u terapiji održavanja 23,7 mjeseci. Ispitanici svrstani u kategoriju pušača imali su srednje vrijeme preživljavanja inhibitorima tirozin kinaze u terapiji održavanja od 9,3 mjeseci. Poredeći ove dvije grupe (nepušači/pušači) nije uočena statistička značajnost u dužini preživljavanja sa inhibitorima tirozin kinaze $\mathrm{u}$ terapiji održavanja $\mathrm{p}>0,05$.

Tabela 7. - Vrijeme preživljavanja sa inhibitorima tirozin kinaze u terapiji održavanja Ženski Muški Nepuš Pušači pol pol ači

\begin{tabular}{|c|c|c|c|}
\hline $\begin{array}{l}\text { Srednje vrijeme } \\
\text { preživljavanja sa } \\
\text { inhibitorima tirozin } \\
\text { kinaze } \\
\text { u terapiji održavanja }\end{array}$ & $\begin{array}{cc}20,6 & 20,6 \\
\text { mjeseci } & \begin{array}{c}\text { mjesec } \\
\text { i }\end{array}\end{array}$ & $\begin{array}{c}23,7 \\
\text { mjeseci }\end{array}$ & $\begin{array}{c}9,3 \\
\text { mjeseci }\end{array}$ \\
\hline
\end{tabular}

Srednje vrijeme preživljavanja pacijenata kod kojih su inhibitori tirozin kinaze primjenjeni $\mathrm{u}$ prvoj liniji iznosi 13 mjeseci. Srednje vrijeme preživljavanja pacijenata kod kojih su inhibitori tirozin kinaze primjenjeni u terapiji održavanja iznosi 19,2 mjeseci. Poredeći srednje vrijeme preživljavanja pacijenata sa inhibitorima tirozin kinaze u prvoj liniji i u terapiji održavanja nije uočena statistička značajnost $\mathrm{p}>0,05$.

Tabela 8. - Vrijeme preživljavanja u odnosu na vrijeme primjene inhibitora tirozin kinaze

Prva linija Terapija održavanja

Srednje vrijeme preživljavanja u odnosu na vrijeme primjene inhibitora tirozin kinaze

\section{3} mjeseci
19,2 mjeseci

\section{DISKUSIJA:}

Segment stanovništva kod koga je najveća vjerovatnoća za pojavu karcinoma pluća su osobe starije od 50. godina sa istorijom pušenja. Prosjećna starosna dob ispitanika je 61. godina. Rezultati studije su u skladu sa podacima iz literature koji navode da je karcinom pluća bolest starije životne dobi ${ }^{[14]}$. Karcinom pluća se sreće u svega $2,3 \%$ pacijenata mlađih od 40 . godina te $u$ svega $5 \%$ pacijenata starijih od 80 . godina.
Literaturni podaci o populaciji oboljelih pokazuju da je histološki tip adenokarcinoma pluća češći kod žena i nepušača ${ }^{[15,16]}$. Adenokarcinom pluća je u $28 \%$ slučajeva zastupljen u muškoj populaciji, a u $42 \%$ slučajeva u ženskoj populaciji. $U$ studiji je zastupljenost adenokarcinoma $u$ muškoj populaciji u skladu sa literaturnim podacima ali je puno viša $(72,5 \%)$ u ispitanika ženskog pola.

U odnosu na pušački status rezultati studije potvrđuju navode literature i pokazuju dominantnost oboljelih od adenokarcinoma pluća $u$ kategoriji nepušača. U studiji je u podrgupi pušača detektovan veći postotak pozitivnosti EGFR mutacija u odnosu na literaturne podatke $(27,5 \%$ naspram 5-10\%).

U studiji je za klasifikaciju stepena proširenosti tumora korištena sedma revidirana TNM klasifikacija iz 2009. godine. Stadijum bolesti oboljelih od nemikrocelularnog karcinoma pluća u korelaciji je sa petogodišnjim preživljavanjem. Pacijenti u IV stadijumu bolesti postižu petogodišnje preživljavanje u svega $2 \%$ slučajeva [17].

U analiziranoj populaciji, najviše pacijenata je u IV stadijumu bolesti $(58,6 \%)$.

Prisustvo aktivirajućih EGFR mutacija je ključan faktor za uključivanje inhibitora torozin kinaze u terapiju oboljelih od karcinoma pluća. Najčešće prisutne mutacije su delecija na egzonu 19 i mutacija na egzonu 21 (L858R). Ove dvije mutacije čine $90 \%$ u odnosu na sve druge mutacije ${ }^{[18]}$. U studiji je učestalost delecije na egzonu 19 $48,3 \%$, a mutacije na egzonu $2138 \%$. Ukupna učestalost dvije pomenute mutacije je $86,3 \%$, što je neznatno niže $\mathrm{u}$ odnosu na literaturne podatke $[18,19]$.

U većini do sada objavljenih studija odnos ispitanika prema polu (ženski/muški) kod kojih je dijagnostikovan adenokarcinom i kod kojih je rađeno testiranje na prisustvo EGFR mutacija je iznosio $1,6: 1$ u korist žena ${ }^{[18,19,20]}$. U našoj studiji taj odnos je 2,6:1 u korist žena.

Primjena inhibitora tirozin kinaze u prvoj liniji je indikovana u slučaju prisustva aktivirajućih EGFR mutacija. U našoj studiji kod 10,3\% ispitanika je detektovana mutacija koja implicira rezistenciju na prvu generaciju inhibitora tirozin kinaze, a u $89,7 \%$ ispitanika su detektovane 
mutacije koje impliciraju primjenu inhibitora tirozin kinaze ${ }^{[21,22]}$.

U našoj studiji se vidi da terapija inhibitorima tirozon kinaze iz tehničkih razloga nije provedena $\mathrm{u}$ svih pacijenata sa indikacijom za primjenu inhibitora tirozin kinaze. Jedan od razloga je dužina čekanja rezultata detekcije EGFR mutacija, a drugi je ograničenje broja pacijenata od strane nadležnog Fonda zdravstvenog osiguranja.

Studija pokazuje da je srednje vrijeme trajanja tretmana inhibitorima tirozin kinaze duže od godinu dana. Srednje vrijeme trajanja tretmana je kraće ukoliko se lijek primjeni u prvoj liniji u odnosu na terapiju održavanja.

Srednje vrijeme trajanja tretmana inhibitorima tirozin kinaze je duže kod ispitanika muškog pola bez obzira na vrijeme primjene (prva linija/terapija održavanja) uz naznaku da je razlika u dužini trajanja tretmana inhibitorima tirozin kinaze $u$ odnosu na pol (ženski/muški) manja ako je lijek primjenjen u terapiji održavanja.

Srednje vrijeme trajanja tretmana inhibitorima tirozin kinaze u kategoriji nepušača je duže ako je lijek primjenjen u terapiji održavanja.

Studija pokazuje da je srednje vrijeme preživljavanja duže od godinu dana. Srednje vrijeme preživljavanja je kraće ukoliko se lijek primjeni u prvoj liniji terapije, ali prelazi godinu dana. Razlika u vremenu preživljavanja kod ispitanika ženskog pola je znatno veća ako se lijek primjeni u terapiji održavanja. Razlika u vremenu preživljavanja kod ispitanika muškog pola je neznatno veća ukoliko se lijek primjeni u prvoj liniji terapije. Vrijeme preživljavanja je isto bez obzira na pol ispitanika ako se lijek primjeni u terapiji održavanja. Vrijeme preživljavanja u kategoriji nepušača je dvostruko duže ukoliko se lijek primjeni u terapiji održavanja. Sve uočene pojavnosti nemaju karakteristiku zakonitosti (statistički nesignifikantne).

\section{ZAKLJUČAK:}

Ključni element $\mathrm{u}$ odabiru pacijenata sa adenokarcinomom pluća za primjenu terapije inhibitorima tirozin kinaze jeste detekcija EGFR mutacija.

Studija potvrđuje navode literature o dominantnosti histološkog tipa adenokarcinoma te češćoj pojavnosti u ženskoj populaciji i u kategoriji nepušača.

$\mathrm{U}$ ispitivanoj populaciji najveći broj pacijenata je u IV stadijumu bolesti.

Ukupna učestalost dvije najčešće mutacije (delecija na egzonu 19 i mutacija na egzonu 21) je $86,3 \%$.

Provođenje tretmana inhibitorima tirozin kinaze u prvoj liniji je otežano u kliničkoj praksi (dužina čekanja rezultata testiranja i lista čekanja).

Srednje vrijeme trajanja tretmana je duže ukoliko se lijek primjeni u terapiji održavanja i u pacijenata koji su svrstani u kategoriju napušača te kod ispitanika muškog pola.

Srednje vrijeme preživljavanja je duže ukoliko se lijek primjeni u terapiji održavanja, kod ispitanika ženskog pola i u ispitanika svrstanih u kategoriju nepušača.

\section{LITERATURA:}

1. Baslega J. Why the Epidermal Growth Factor Receptor? The Rational for Cancer Therapy. Oncologist 2002;7:2-8,

2. Bishop J.M.: The molecular genetics of cancer. Science 235: 305-311, 1987,

3. Phuong Khanh HM. Edwards SK. New Biological Agents in the Treatmant of Advanced Non- Small Cell Lung Cancer. Semin Respir Crit Care Med 2005;26 (3):323-332,

4. Jemal A, Siegel R, Ward E, et al. Cancer statistics, 2007. CA Cancer J Clin 2007;57(1):43-66,

5. Shibuya $K$, Fujisaw $t$, Hoshino $H$, et al. Fluorescence bronhoscopy in the detection of preinvasive bronchial lesions in patients with sputum cytology suspicious or positive for malignancy. Lung Cancer 2001;32(1):19-25,

6. Sato M, Sakurada A, Sagawa M, et al. Diagnostic results before and after introduction of autofluorescence bronhoscopy in patients suspected of having lung cancer detected by sputum cytology in lung cancer mass screening. Lung Cancer 2001;32(3):247-253,

7. Stenbygaard LE, Sorensen JB, Olsen JE. Metastatic pattern in adenocarcinoma of the lung. An autopsy study from a cohort of 137 consecutive patients with complete resection. J Thorac Cardiovasc Surg 1995;110:1130-1135,

8. Croce CM. Oncogenes and cancer. (Jan 2008.) N Engl J Med 356(5):502-511. DOI:10.1056/NEJMra072367.PMID 18234754. 
9. Erman M. Molecular mechanisms of signal transduction: Epidermal growth factor receptor family, Vascular endothelial growth factor family, Kit, Plateled-derived growth factor receptor, Ras. Journal of BUON 2007;12(1):83-94,

10. Miller VA, Riely GJ, Zakowski MF, et al. Molecular characteriistics of bronchioloalveolar carcinoma and adenocarcinoma, bronchioloalveolar carcinoma subtype, predict response to erlotinib. J Clin Oncol 2008;26:1472-1478;

11. Shigematsu H, Lin L, Takahashi T, et al. Clinical and biological features associated with epidermal growth factor receptor gene mutations in lung cancers. J Natl Cancer Inst 2005;97:339-346,

12. Tsao, M. S. et al. Erlotinib in lung cancer molecular and clinical predictors of outcome. $\mathrm{N}$ Engl J Med 2005; 5, 13-144,

13. Mok TS et al. Gefitinib or carboplatiin-paclitaxel in pulmonary adenocarcinoma. N Engl J Med 2009; 361, 947-957.,

14. Schottenfeld D, Epidemiology of Lung Cancer. In: Pass HL, Mitchell JB, Johnson DH, Turrisi AT. Lung Cancer. Lippincott-Raven, Philadelphia New York, 1996:305-321,

15. Shibuya K, Fujisaw T, Hoshino $H$, et al. Fluorescence bronhoscopy in the detection of preinvasive bronchial lesions in patients with sputum cytology suspicious or positive for malignancy. Lung Cancer 2001;32(1):19-25,

16. Sato M, Sakurada A, Sagawa M, et al. Diagnostic results before and after introduction of autofluorescence bronhoscopy in patients suspected of having lung cancer detected by sputum cytology in lung cancer mass screening. Lung Cancer 2001;32(3):247-253,

17. Rami-Porta R, Crowley JJ, Goldstraw P (February 2009). „The revised TNM staging system for lung cancer". Annals of Thoracic and Cardiovascular Surgery 15(1):4-9. PMID 19262443,

18. Philip TC, Timothy CA. Lung Cancer GenotypeBased Therapy and Predictive Biomarkers. Arch Pathol Mab Med2012;136:1482-1492,

19. Kraweczyk P, Ramlau R, Chorostowska-Wynimiko J, Powrozek T, Levandovska MA, Limon J et al. The efficacy of EGFR gene mutation testing in various samples from non small cell lung cancer patients: multicentre retrospective study. J Cancer Res Clin Oncol 2015;141:61-68,

20. Shim HS, Lee DH, Park EI, Kim SH. Histopatologic Characteristic of Lung Adenocarcinomas with Epiderma Growth Factor Receptor Mutation in the International Association for the Study of Lung Cancer/American Thoracic Society/European Respiratory Society Lung Adenocarcinoma Classification. Arch Pathol Lab Med 2011;135:1392-1398,

21. Keedy VL, Temin S, Somerfield MR, et al. American Society of Clinical Oncology provisional clinical opinion: epidermal growth factor receptor (EGFR) mutation testing for patients with advanced non-smallcell lung cancer considering first-line EGFR tyrosine kinase inhibitor therapy. J Clin Oncol 2011; 29: 2121-7,

22. Pao W, Miller VA, Politi KA, et al. Acquired resistance of lung adenocarcinomas to gefitinib or erlotinib is associated with a second mutation in the EGFR kinase domain. PLoS Med 2005; 2: e73.

ABSTRACT: Molecular pathology of lung adenocarcinoma, it is probably better defined as compared to other tumor types, due to its frequency, and surgical accessibility of its success in the identification of clinically important mutations in this type of cancer. EGFR (eng. Epidermal Growth Factor Receptor) mutations have been clinically most relevant mutations in lung cell carcinoma, as well as significant predictors for the therapy target chemotherapeutics. The transmembrane glycoprotein from the group of epidermal growth factor receptor is present in $10 \%$ to $15 \%$ of cases of advanced non-small cell lung cancer.

The study included 29 patients in the period from Mas 2012 to December 2016 in the Department of Pulmonary Diseases University Clinical Centre $R S$ implemented diagnostic and therapeutic treatment of NSCLC. All patients cytology and/or histologically confirmed adenocarcinoma of the lung, and in the Department of Pathology, University Clinical Centre RS spent additional molecular testing of existing material. The study confirms the dominance of the cited literature were adenocarcinomas and more frequent incidence in the female population and in the category of nonsmokers. The study shows that the mean duration as well as the median survival longer than one year.

Kontakt osoba: Lora Novaković Lacković 
Klinika za plućne bolesti UKC RS, Zdrave Korde 1

78000 Banja Luka, Republika Srpska,BiH

lora.novakovic@kc-bl.com,telefon: +38751343209 